Ђорђе Деспић

Филозофски факултет Универзитета у Новом Саду

despy@eunet.rs
УДК 821.163.41.09-1 Павловић М. 821.163.41.09-1 Павловић М. Оригиналан научни рад

\title{
ХРАМ И ПРЕОБРАЖАЈ КРОЗ МИТСКО-АНТРОПОЛОШКУ МИСАО МИОДРАГА ПАВЛОВИЋА ${ }^{1}$
}

Павловићева књига Храм и преображење представља пример есејистичког напора да се одређене тачке човекових културних и духовних основа сагледају првенствено кроз митско-антрополошку и филозофско-религијску призму. Притом, ову есејистичку интенцију настојимо да доведемо у (поетичку) везу са његовим песничким опусом, будући да су антрополошки и метафизички проблеми који у овим текстовима занимају Павловића, попут насловних феномена храма и преображења, али и ритуала и мита, од самих почетака присутни и у његовој поезији, као и у другим есејистичким књигама попут Поетике жртвеног обреда или Говора о ничем.

Кључне речи: есеј, поезија, храм, преображење, мит, ритуал, двојник, симболизација, интертекст

У средишту нашег разматрања Павловићевих есеја налазе се они текстови који су окренути најпре митско-антрополошким питањима, и првенствено ћемо их разматрати у контексту његовог Храма и преображења (1989), али ћемо се повремено освртати и на две његове књиге из 1987. године, Поетику жртвеног обреда и Говор о ничем². Све три представљају заправо резултат исте духовне заокупљености човековим културним коренима. Аутор у њима развија и надограђује ону линију есејистичке мисли која свој фокус усмерава ка просторима обреда, жртве, храма, мита, ка самом изворишту језичког и културног, као и као оним књижевним делима из светске књижевности која су битно условљена митом (посебно у Поетици жртвеног обреда). У њима је

1 Рад је настао у оквиру Пројекта 178005 „Аспекти идентитета и њихово обликовање у српској књижевности“.

2 За потребе нашег рада користићемо се трећим, прегледаним издањем Поетике жртвеног обреда из 2000. године (Павловић 2000). 
приметан подстицај који долази из других хуманистичких дисциплина, попут археолошких налазишта древних цивилизација (откриће винчанске културе, рецимо), или пак ширих антрополошких истраживања. ${ }^{3}$ Добар део ових есеја бави се, тако, антрополошким и културним исходиштима која почивају у ритуалу и миту, али и неким универзалним духовним питањима и вредностима, посебно у Говору о Ничем (Павловић 1987), с тим да ће у Поетици жртвеног обреда настојати да такву митско-антрополошку формулу човекове структуре препозна и анализира у књижевним делима.

Такође, у раду ћемо настојати да овај тематско-есејистички план представимо кроз могуће кореспондирајуће релације према Павловићевом песничком опусу, наслућујући да су и у њима, као и у другим његовим критичкоесејистичким текстовима, садржане нити једног вишег степена стваралачке кохеренције.

Кьигом Храм и преображење Павловић наставља да развија интересовање за митско-антрополошке основе човекове културе. „Окренутост сакралним грађевинама и њиховом дејству на човекову унутрашњу дубину“ (Павловић 1989), како каже Павле Зорић у рецензентском уводнику, средишња је и проблемска усмереност ових страница. Но ова књига осим што отвара нове аспекте у промишљању храма и слутње преображења, она их добрим делом есејистички и варира, будући да се овим питањима већ бавио у својим песничким књигама. ${ }^{4}$ Притом, своју широку и убедљиво засновану културолошку упућеност Павловић потврђује и у оним поглављима која додатно разматрају већ артикулисане теме из Поетике жртвеног обреда, попут жртвеника, или храма и маске, рецимо. Рецепција Павловићевог Храма и преображења оскуднија је у односу на његова друга, сродна остварења, али вреди нагласити оцену

3 У том смислу, одређеног трага на Павловића оставиће и идеје које стижу из тзв. „високог структурализма“, односно онога што Клод Леви-Строс назива структуралном антропологијом, у оквиру које интересовање за мит иде према препознавању језика као универзалног система понашања и функционисања свих култура. Но, Павловић је опрезан према оваквој идеји и, како то истиче и Сретен Петровић, према идејема Леви-Строса односи се „не без критичког цинизма“ (Петровић 1988) будући да, по Павловићу, ми данас ипак не можемо боље знати у шта је древни човек веровао, као што је то претпостављао структурализам.

4 Овим феноменима Павловић ће се знатно раније бавити и у својој поезији. Књига Светли и тамни празници најбољи су пример за такву тематизацију, посебно циклус Метаморфозе и песме Слуитња проперода и Преображај. 
Александра М. Петровића по коме ова књига, заједно са Поетиком жртвеног обреда, представља „врхунце мисаоне креативности“ (Петровић 1990).

О градњи храма, као о првим импулсима раног човека који је хтео да јасно омеђи свој култски и културни простор, Павловић у својој Поетици говори више него убедљиво (Павловић 2000) ${ }^{5}$, али више у оном начелном и елементарном поимању храма, и ослањајући се најпре на примере из далеке историје. Овде се пак акценат ставља и на ране хришћанске храмове, базилике, које га привлаче како својим настајањем и постојањем, тако и својим нестајањем. За аутора храм је био покретач богатих и суштинских духовних процеса, и у његовом пореклу треба видети човеков „културни нагон“ који је осећао, као и потребу за духовном концентрацијом, потребу да у себи „издвоји један унутарњи простор имагинације и самопосматрања“ (Павловић 1989: 29). По Павловићу градњу храма треба схватити као слутњу преображења, јер је његово настајање увек везивано са феноменом смрти и симболиком поновног ницања, било да је грађен на гробу или над гробом, било да је сам храм представљао гроб или гробницу, попут египатских пирамида или хришћанских катакомби. Отуда човекова тежња ка сублимацији, и уопште духовни процеси који се у њему одвијају за аутора неретко имају исходиште у феномену смрти: „Смрт је одувек катализатор метафизичких осећања у човеку“ (Павловић 1989: 29). Ову тезу треба прихватити и као тачну мисао, али и као непорецив аутопоетички рефлекс који заједно са неким другим сродним мислима, попут оне из Дневника пене да је „смрт велико искушење имагинације“ (Павловић 1972: 25), творе основу за оно тако често и ефектно уметничко конституисање есхатолошке имагинације у његовом песништву. ${ }^{6}$

Међу оним местима која по нама највише привлаче пажњу, свакако је његово промишљање функције храма којом се успоставља аналогија са човековим положајем „док је у „футроли“ другог тела, у дубини мајчиног дроба“ (Павловић 1989: 30). Наиме, Павловић поставља очуђујуће питање: није ли храм ту да обнови положај фетуса, чиме храм као да постаје нека врста супституције и вид духовног материнства? На овом нивоу храм, чини нам се, мора бити доведен у везу са пећином коју је као простор са свим родитељским елементима

5 Видети поглавље: Мегалити и први храмови.

6 Довољно је присетити се само неких песама из Млека искони (Павловић 1962) или Велике скитије (Павловић 1969), попут Агамемнон се јавља или Посечени кнез се сећа. 
препознао још праисторијски човек. О том уочавању сличности облика пећине са родитељским особинама саме земље, а у контексту жртвене обредности, Павловић је већ говорио у својој Поетици жртвеног обреда, наглашавајући и да у цртежима и осликавању пећине треба видети магијске обреде упућене „генеративној моћи земље“ (Павловић 2000: 24). Тиме функцију и смисао пећине за палеолитског човека, које у Поетици подробно разматра, у Храму и преображењу додатно развија, и то уводећи једну онеобичену асоцијативност која у храму препознаје фигуративну припрему новог рађања, односно слутњу преображења кроз родитељску метафору.

Ова игра асоцијативног повезивања храма и пећине кроз мотив човековог фетуса за нас има оправдану и убедљиву симболичко-антрополошку заснованост. Но, чини нам се такође, да не би било неоправдано довести у везу овај аспект Павловићевог промишљања храма са Турнијеовим уметничким решењем једне Робинсонове архетипске ситуације. Наиме, у време док исписује ове странице Павловићу је познат роман Мишела Турнијеа Петко или лимбови Пацифика, и искуство овог „новог“ Робинсона. За овај оквир разговора, међутим, посебно је интересантна она ситуација у којој се Турнијеов јунак наглашено враћа телурском принципу, принципу обожавања земље (треба ли подсећати на стихове Павловићевог Епитафа словенског прапесника). У том свом истраживању јунак у једном моменту открива пећину у чијој дубини утроби, проналази облик који савршено одговара његовом облику у фетусном стању. Уклопивши се у њега, Робинсон поново доживљава искуство пренаталног склада, али и откровење божанског, стваралачког принципа. Тиме дубина пећине добија сакрално-родитељско обележје, док ће напуштање фетусног жљеба и излазак из пећине за Турнијеовог јунака попримити елементе (симболичког) преображаја (Турније 1990: 69-75).

За Павловића мит је и даље велика тема, и из књиге у књигу (што песничку, што есејистичку), присутна је његова изразита тежња ка наглашавању значаја митских исходишта за (савременог) човека. У Храму и преображењу, између осталог, он ће истаћи антрополошку посебност мита као феномена језички израслог из ритуалних радњи, одричући му притом било какву могућност књижевног класификовања: „Мит није исто што и уметничко дело које га представља, нити нарација која га прича, иако мит етимолошки 
значи неку причу“. Такође, за разлику од бајке која „спада у књижевне облике и образује сопствену врсту“, аутор сматра да „мит није књижевни облик и не образује никакав жанр, ни књижевни, ни неки други“. ${ }^{7}$ Једно је, међутим, тежња ка дубљим антрополошким, културолошким, повесним захватањем у порекло, смисао и функцију мита, па и ритуала на којем се сам мит темељи, а друго његова језичка/ текстуална реалност која сама собом сведочи о специфичном уобличавању и изражавању животних појава и искуства света. Инсистирање на његовој апсолутној посебности у том случају избацило би га уопште из простора књижевности, што његова језичка, структурна, наративна егзистенција ипак не дозвољава. Отуда и бајка и мит што специфичним, што одређеним структурним особинама припадају оном типу облика који књижевна теорија именује ,једноставним облицима“. 8

Но, за Павловића митски догађај није само прича (Павловић 1989: 44), нити је митска прича само структура (Павловић 1989: 45), већ је мит нешто тајанствено и сакрално, са мистичним дејством по човека или природу (Павловић 1989: 44). Павловић прихвата митску причу као сведочанство о преображају, будући да мит као деритуализација (о чему највише говори у Поетици), подразумева превођење из обредног чина у говор. У томе, дакле, види њену сакралност - понајвише јер је „сама собом пример преображавања“ (Павловић 1989: 45). Ауторова доследност у промишљању мита садржана je у томе што му претпоставља да његова снага не произилази из повратка у прошлост, већ лежи у његовој сталној актуелности. Ту моћ произвођења новог значења у савремености који мит у себи носи, Павловић несумњиво аутентично осећа и артикулише у својим есејима још од Дневника пене, док у поезији обележава вероватно највећи део његовог опуса. Иако јесте неки вид праисторијске и недодирљиве стварности, мит ипак егзистира кроз време и утиче на актуелни живот, стварајући и преображавајући не само оно што аутор жели да нагласи у овој књизи - нове односе, квалитете и нивое на сакралном плану - већ и постајући непорецив услов живота и непрестаног преображаја саме књижевне уметности.

7 Храм и преображење, стр. 41

8 Један од важнијих доприноса проучавању и систематизовању облика који се по својим особинама издвајају од осталих књижевних жанрова, даће Андреас Јолес својом књигом Једноставни облици. 
По овом начину мишљења, по промишљању мита и антрополошких и архетипских феномена, ове странице више нагињу филозофско-мистичном дискурсу Говора о Ничем:

Пре хаоса била је суштина, јака као семе, идеја којој није требало преображење, симбол који је живео недељив као свако право постојање. Кад у митској имагинацији бива откривено како од једне нимфе или полубогиње постаје дрво, то је указивање на правац у којем метаморфозе заиста иду...

Мистерија није обнова тела нити припремање његовог вечног живота, него повратак у језгро, у семе, у идеју која више не ствара. Зато се језик говори као низ, следство које иде унапред, у даљину, али његов смисао иде уназад, у близину која се препокрива, сумира, појачава, тиме постаје божанска и смисао постаје најзад истина. Језик говори једно, мисли друго и стиже на тачку у којој постоји а да се и не говори. Тако се и у храму врши једно преображење унапред које се шаље у свет и са мишљу да га обнавља, и друга која нас враћа себи, смањује, и чије откровење чини да од храма остаје само прибор (Павловић 1989: 45-46).

Мит и преображај за Павловића представљају знаке исконског покрета, једнако као и вид мистичне синтезе у временској и духовној категорији: тек из тачке таквог свеопштег сустицања ниче осећање сакралног.

Тако у поглављу Сублимација ритуала, можемо препознати надовезивање мисли на већ изнета разматрања у Поетици жртвеног обреда и Говору о Ничем. То подразумева ширење и дописивање односа који постоји између обредног и оног стваралачког, уметничког чина на ранијем ступњу људске културе. Јер уметност за њега настаје из симболизације која већ постоји у самом жртвеном ритуалу, подсећајући притом да се процес симболизације прво одвија на људској крвној жртви, потом на животињској, која се касније замењује митским предањем и сакралном скулптуром (Павловић 1989: 58). Но, даљи степен етеризације ритуала одвија се у самом човеку у оквиру духовног откровења и „на прагу Неизрецивог“, где се можда и рађа важно песничко питање способности језика да изрази то неизрециво, или то Ништа, како ће 
га варијантно именовати у књизи Говор о Ничем. Павловић ту одваја поезију која је „идеологизована“ јер остаје на нивоу жртвених обреда, у коју сврстава хомерске химне, Пиндара, поезију Симеона Новог Богослова, рецимо, док оној неидеологизованој уметности која симболизује велику духовност, али остаје још увек уметност, придружује пре свих Хелдерлина, енглеске метафизичке песнике и Дантеа, о чијем ће Новом животу управо с аспекта сублимације и идеализације, више говорити у Читању замишљеног (Павловић 1990). Но Павловић овде жели да истакне да је принцип и феномен Преображења колико сакралне толико и уметничке природе, те штавише, да Преображење прожима до сржи и човеково мислеће, и религиозно, и родитељско биће:

Уметник је за Преображење: да се телесна реалност човекова, задржавајући облик, претвори у нешто трајно, надземаљско и свето. Мислилац је за распеће: да прође кроз реалност негације и да телесно полако замени апстрактном схемом: крстом. Мистик нуди васкрсење једном и другом. Он говори из аниме. Говори као земља и жена: све ће опет бити. Кад и где и у ком облику, није важно. Важно је бивање. „Неко ће постојати за нас““, говори родитељ, говори из неизрецивости, која се привиђа као дух, али долази заправо из материје саме, и њене моћи да створи живот, не питајући се о значењима (Павловић 1989: 59).

У поглављу Митски двојници, аутор настоји да проблематизује човеково самоспознавање. Наиме, он питање одрживости идеје да човек треба да спозна себе помоћу себе самог, поставља у складу са митскоантрополошком и културолошком оријентацијом у промишљању човековог битисања. Самоспознаја значи откривање и потврду властитог идентитета, али за Павловића прави идентитет није у човеку већ изван њега, те се „мери и спознаје својим митским двојником“. Ова теза је још једна варијација истицања важности коју архетипска ситуација има за човека. С друге стране, иако то не експлицира, може се пропознати да он овде наслућује и једну дубоку истину природе књижевно-уметничког дела: да нема дела без свог „двојника“, да је спознавање књижевног дела могуће тек захваљујући бројним „двојницима“ 
који му претходе на различитим нивоима његовог идентитета. ${ }^{9}$ Тиме је присутна свест о интертекстуалној природи књижевности, те неопходности да се дело разуме и прихвати кроз специфична контекстуална и компаративна сагледавања.

И у Павловићевој поезији, и у његовој есејистици, архетипске ситуације представљају повлашћено место. Ова се чињеница може најпре разумети уколико његово стваралаштво посматрамо кроз аспект повести и културе (или повести културе), односно уколико прихватимо тезу, која се сама по себи намеће, да је Павловић велики део свега што је написао учинио кроз призму антрополошких интересовања. Архетипске ситуације су за њега уткане у човеково онтолошко ткиво, као и у његово културно порекло, те тако представљају и незаобилазан темељ великог дела литературе. Отуда, на пример, проналази везу између литературе бродолома и чина крштења, указујући на конституисање симболичке везе између ове архетипске ситуације и чина сакралног ритуала. У оба случаја симболичко значење лежи у спасењу, и аутор над том уоченом релацијом убедљиво медитира у поглављу Иницијатичко море, бродолом. Аутор се позива на бројне примере из митова, античких и библијских, на искуство страдања у води и спасењу из ње, помињући у различитим контекстима Јону и Гилгамеша, Одисеја и светог Павла.

Но када је у питању модерна литература, Павловић помиње само савременог француског романописца Мишела Турнијеа, а алузивно и наслов већ помињаног његовог романа који одговара теми: Петко или лимбови Пацифика. У интервјуу који је дао часопису Браничево 1990. године, он и открива да од страних писаца са „поетским уживањем чита Мишела Турнијеа, Данијела Дефоа, Пушкина, Гогоља...“ (Павловић 1990: 16). У поглављу којим се сада бавимо, међутим, не помиње се Дефоово дело Робинсон Крусо, иако је то можда данас и најпознатији пример тематизовања бродоломничке ситуације, и иако је то онај „митски двојник“ који ће директно подстаћи Турнијеа да напише своју „верзију“ Робинсоновог случаја. ${ }^{10}$ Турнијеов роман је према томе Павловићу

9 На овом месту треба подсетити на интересантан увид који открива Јован Делић у вези са Павловићевом песмом Кантакузин из Књиге старословне (1989), у којој сам лирски јунак, Кантакузин, по питању „тежње за обухватањем и исказивањем цјеловитости свијета“, представља заправо самог „Павловићевог двојника, узора и претечу“ (Делић 2010: 59).

10 Јер иако је, уопштено говорећи, све слично, све је опет и другачије. Дефоова евроцентричност и логоцентричност, као и све остале филозофско-идеолошке импликације које су везане за Европу на прелазу из 17. у 18. столеће, у Турнијеовом роману подлежу изузетном, луцидно-романсијерском преиспитивању. Његов роман 
тада, 1989. године, и уопште тих година, вероватно ако не свежији од Дефоовог а оно сигурно привлачнији, и на то упућује барем још једна архетипска ситуација. У питању је она која Робинсона доводи у позицију првог човека, Адама. Ова позиција намеће се и код Дефоа, свакако, али нема једне важне димензије које код Турнијеа има, а то је љубавно општење с природом, на коју наилазимо касније и код Павловића у његовој песми у прози Дрво (Павловић 1996). То љубавно општење с природом може се довести у везу са човековим раним свепрожимањем с природом, али и са видом ритуалног чина којим природа треба да се пробуди и учини плоднијом и даровнијом, што је важан антрополошки аспект о којем говори у Поетици жртвеног обреда. Пишући Дрво, дакле, Павловић је по нашој, чини нам се сада до краја оправданој и заснованој претпоставци, у потпуности свестан Турнијеовог текста, и у основи овако остварене имплицитне цитатности за Павловића Турнијеов Робинсон стоји као непосредан подстицај за ново тематизовање једног библијског мотива. Отуда је Дрво пример где литература - у овом случају библијски мит добија нову, онеобичену, уметничку интерпретацију захваљујући укрштању са Турнијеовим еротским мотивом, што је још један доказ да књижевност живи од књижевности и превођења. Такође, овај пример још један је прилог нашој тези да Павловићева поезија чак можда више извире из есејистике него што би било обрнуто, што указује на интелектуалну и ерудитну основу његовог стварања. Циклуси песама у прози у којима ће тематизовати архетипске симболе (Камен, Планина, Дрво, Пећина) (Павловић 1996), тако, готово засигурно добар део свог подстицаја дугују есејистичким књигама које аутор пише у другој половини осамдесетих година прошлог века.

У поглављимаВреме изаблудес временоми Непостојећавечност, дискурс се више приближава филозофском тону и баратању апстрактним категоријама попут прошлости и будућности, реалности и иреалности, егзистенције и бескрајности, цикличности и синхроницитета. Ове медитације откривају свога аутора као мислиоца којег привлачи не само егзактна неухватљивост ових феномена, него могућност да се да прилог можда неком будућем и адекватнијем

велика је и бриљантна уметничка расправа са идејама које су владале у Дефоово доба. Те суптилне полемичке паралеле могу се препознати на бројним нивоима, а ми смо се у једном тексту компаративно бавили статусом, фукнцијом и значајем Библије и Божије речи у ова два романа (Деспић 2011) 
дефинисању појма времена, за који слути да у себи носи потенцијално сложенију слику о димензији наше егзистенције. Ако погледамо Павловићеву поезију и спуштање на различите цивилизацијске нивое и културне епохе, схватићемо да је његово промишљање времена у овом есеју из 1979. године, део исте стваралачке свести. Песничка евокација и актуелизација културне, друштвене, духовне повести, израз је настојања да се различити временски пресеци дају у виду нове темпоралне реалности у којој сусрет савремености са прошлошћу нуди једну врсту новог, квалитативног доживљаја човека у времену, односно уметнички вид имагинативног, онтолошког и духовног синхроницитета. Ту идеју, или можда слутњу, најтранспарентније уочавамо у спеву Дивно чудо (Павловић 1982), иако је пригушеније присутна у ширим границама опуса будући да се у њему препознаје интензивно дотицање и егзистенцијалног, и оног духовног искуства историје. Овај поступак преплитања времена, не у наративном већ у епохалном смислу, присутан је и у његовом романсијерском опусу, у Афродитиној ували (Павловић 2001), рецимо, што говори о упорности и доследности стваралачко-интуитивне слутње о могућој сложенијој структури димензије времена.

За Павловића целокупна основа света произилази из процеса преображења. Сам животни и природни циклус постаје јемац обредног и митског мишљења, те симболичност жртвеног ритуала, једнако као и значења митова (Персефона, Генеза, Апокалипса), непрестано упућује на дожевљај света и космоса као на чин непрекидне метаморфозе. Од будистичког схватања метаморфозе као свемирског здруживања свих бића у аноргански венац егзистенције (Павловић 1989: 97), Павловићу је ближа хришћанска идеја храма као инструмента духовног преображења:

Храм нам даје слутњу тог сасвим другог телесног руха које добијамо у метаморфози, он нас подстиче на преображај, преламајући светске енергије нама у сусрет, у нашем правцу, нуди нам моделе нашег изгледа који би значио успон ка крајњем облику, нама несагледљивом. Храм ставља тачку на наше простирање, појачава контуру наше телесности и тиме ограничава кретање по бескрају, чиме појачава силу унутрашњих маневара. Храм је и једини сведок нашег преображаја, који не видимо ни ми, ни наши ближњи 
(Павловић 1989: 97-98).

Књигу затварају два текста, Храмови Каџураха и У московској цркви Радост уцвељених, који есејистички дискурс са антрополошко-филозофске равни преводе на раван путописне прозе. Као да у сусрету путописца са индијским и руским храмовима простор апстрактних категорија и митскоантрополошких духовних феномена на моменат добија неки облик своје оваплоћености: антрополошку рефлексију замењује импресија, естетски доживљај, али и осећање тихе духовне омамљености: преображење у храму добија своје дискурсно сведочење.

\section{ЛИТЕРАТУРА}

Делић, Јован (2010). Уз поетику Миодрага Павловића. Зборник радова: Песништво и књижевна мисао Миодрага Павловића. Београд: Институт за књижевност и уметност; Учитељски факултет.

Деспић, Ђорђе (2011). Библија као интертекст у романима „Робинсон Крусо“ Данијела Дефоа и „Петко или лимбови Пацифика“ Мишела Турнијеа, у: Преживети у тексту. Београд: Службени гласник.

Павловић, Миодраг (2001). Афродитина увала. Београд: Просвета.

Павловић, Миодраг (1969). Велика скитија. Сарајево: Свјетлост.

Павловић, Миодраг (1987). Говор о ничем. Ниш: Градина.

Павловић, Миодраг (1972). Дневник пене. Београд: Слово љубве.

Павловић, Миодраг (1982).: Дивно чудо, Београд: Књижевне новине.

Павловић, Миодраг (1996). Изабране и нове песме. Београд: Просвета.

Павловић, Миодраг (1990). Интервју. Браничево. Број 1-2: 16.

Павловић, Миодраг (1962). Млеко искони. Београд: Просвета.

Павловић, Миодраг (2000). Поетика жртвеног обреда. Београд: Просвета.

Павловић, Миодраг (1989). Храм и преображење. Београд: Sfairos.

Павловић, Миодраг (1990). Читање замишљеног. Нови Сад: Светови.

Петровић, Александар М. (1990). Жртвени обред, храм и преображења, у темељу поетике Миодрага Павловића. Браничево. Бр. 1-2: стр. 73-85. 
Петровић, Сретен (1988). Ка аутономији књижевног дела. Градина. Бр. 5: 106 .

Турније, Мишел (1990). Петко или лимбови Пацифика, прев. Гордана Стојковић. Нови Сад: Братство-јединство.

Đorđe Despić

\section{TEMPLE AND TRANSFORMATION WITHIN MYTHOLOGICAL AND ANTHROPOLOGICAL THOUGHT OF MIODRAG PAVLOVIĆ}

\section{Summary}

This study focuses on certain essays by Miodrag Pavlović from his book Temple and Transformation, which is a product of the same kind of spiritual inspiration and interest as The Diary of Foam (1972), A Speech about Nothing (1987), and Poetics of the Ritual of Sacrifice (1987). In these works, the author develops and upgrades the line of essayistic thought which is directed towards the realms of ritual and myth, as well as the symbolic significance of temple for man's spiritual transfiguration. These essayistic features of Pavlović gravitate towards the very source of man's linguistic, cultural, historical and religious being, a tendency which in different creative shapes and formats also characterizes his poetic opus. Therefore, this paper aims to point out at the competence of Pavlović's essayistic thought and its poetic sociological and philosophical religious orientation, which at the same time clearly corresponds to his poetry. 